\title{
Special features of criminal statistics of criminality in the field of sport
}

\author{
Dmitry Anatolyevich Bezborodov ${ }^{1}$, Andrey Nikolaevich Berestovoy ${ }^{2}$, Roman Mikhailovich \\ Kravchenko $^{1 *}$, Ekaterina Nikolaevna Rakhmanova ${ }^{2}$, and Elena Valentinovna Topilskaya ${ }^{2}$ \\ ${ }^{1}$ Saint Petersburg Law Institute (branch) of the University of Prosecutor's office of the Russian \\ Federation, Chair of Criminal law, Criminology and Penal Law, Saint Petersburg, Russia \\ ${ }^{2}$ North-West branch of the Russian State University of Justice, Chair of Criminal Law, Saint \\ Petersburg, Russia
}

\begin{abstract}
The modern state of criminality and its statistical analysis are an integral part of any criminological research including the field of sport. Besides the main factors forming the crime rate, the data of the judicial statistics are also influenced by the so-called minor factors that are beyond the statistics. The objective of the present research is to reveal the factors influencing the formation of indicators of statistics in the field of sport. The research uses the systematic, structural and functional, comparative and historical, and formal judicial methods that allowed determining the main directions and methods of execution of criminality recording in the field of sport that is highly latent. It was determined that there were discrepancies of the normative requirements with the qualification of wrongful acts that allowed revealing the particular correlation between the changes in the criminal law and the statistical indicators. The overrating of crime detection statistics by the particular changes in parameters of crime committed shall be called additional factors influencing the reliability and objectivity of the statistics. At the same time, the statistics of crime committed in the field of sport are required for prognostic purposes, as well as for preventive purposes, as its absence contradicts the social practice. This problem is especially acute for sportsmen who due to the reasons related, for example, to the harm injured to their health and life, do not have the ability to continue their professional career. It is a systematic approach to registering crimes committed in the field of sport that allows performing the crime prevention in full that can save also the health and life of a sportsman.
\end{abstract}

Keywords: statistics, latency, sport, crime forecast

\section{Introduction}

Fighting against crime is stipulated to a great extent by the quality of statistics $[1,2]$. The results of statistical analysis of criminality determine the crime forecast on the whole in the country and also can be applied to the particular spheres of life of society including sport.

\footnotetext{
* Corresponding author: roman888rus@ rambler.ru
} 
The efficiency of fighting against crime depends upon the depth of understanding the connection of this phenomenon with the characteristics of the "environment", which is understood as various phenomena of social life: demographic and social processes, the degree of economic development, etc. [3; 4, p. 90; 5, pp. 47, 78]. Despite the fact that the "official crime statistics reflect rather completely the existing social phenomena, their tendency, and dynamics, but besides them, other indicators characterizing a crime itself and a law-breaker should also be taken into account" [6, p. 41]. Sharing a fair confirmation of criminologists about the necessity of the systematic approach to the analysis of statistical data of criminality and the necessity of taking into account the impact on it (criminality) [7] by a wide range of social factors, it should be mentioned that when performing most criminological studies, unfortunately, the requirements of the normative acts of the official crime statistics are not taken into account.

To analyze the mechanism of formation of statistical data of criminality and its relations to other social and legal phenomena, the data of reports regarding the criminality in Russia executed by the Ministry of Internal Affairs of Russia were studied, as well as the provisions of the normative acts regulating the procedure of crime statistics and fighting measures against them performed by law enforcement agencies, as well as the federal laws making amendments in the Criminal Code of the Russian Federation.

\section{Methods}

The systematic, structural and functional, statistical, forecasting, and other special methods (formal and logical analysis, comparative and legal research, etc.) were used for this research and that is determined by the character of modern criminality and phenomena related to it.

\section{$3 \quad$ Results and discussion}

The development of forecasts in the field of fighting against crime is based upon the study of the significant volume of social and legal information but first of all, it is based upon the statistical information [8, p. 89].

It should first be mentioned that "statistics, finding and estimating the general properties, determine the common statistic patterns based upon the law of large numbers. It does not explain the internal mechanism of pattern formation; it does not separate the causal dependencies. The search for the statistic patterns is performed by finding and measuring the common properties of the phenomena. The statistic research is always related to the search of regularities, determination of their causal character, etc." [5, pp. 47-48]. The above-said is referred to the legal statistics to the full extent.

However, one stipulation about the interrelation of criminality as a social phenomenon with a wide complex of factors of social, economic, and political character is not enough to determine these regularities. "The degree of reliability of the obtained results of the criminological research is influenced by the objective factors (crime latency, the degree of development of the crime registration and recording system, methods of statistical analysis), as well as the subjective factors (corruption from the side of the law enforcement officials when registering and recording the crimes)" $[9,10]$.

The typical example of latency is criminality in the field of sport. In society, the uncensorious attitude towards some factors of unlawful phenomena in the field of sport is widespread. For instance, some examples of overcoming trauma or disease by a sportsman attract more attention of the fans to his or her personality and the kind of sport in general and sometimes they even become the ground for the filming of all kind as the stories of heroic acts and strength of spirit. However, not every fact of sport traumatism becomes known to 
the general public. "Ignoring the threat of a negative impact of making sport on the health of participants in sports events comes from the false fear of bringing the sport into the public discredit" [10, p. 25]. As a result, no one of the participants in a sports event or training during which he/she was injured makes it public about the trauma and its reasons. The consequences of the impact of these factors are the absence of official statistics about the facts of criminal trespass during sports events.

One of the most significant segments of modern sport is corruption [11, pp. 201-203]. However, it is not reflected in the official criminality statistics in Russia. Thus, in 2019, law enforcement agencies registered 30,991 corruption crimes, and among them, there were 13,867 crimes related to bribetaking (the growth in this category of crimes by $10.7 \%$ in comparison with 2018 was recorded) [12]. The same can be said about the situation with doping. The scandals of last years are well-known; they were well described in the mass media.

At the same time, all official statistic reports for the last three years miss the data of registration and criminal trials committed in the field of sport or in connection with sport.

The same situations are well known to sociologists and criminologists. During many years, they developed and applied mathematical models [13] and sociological methods making it possible to compare the results of the research with the criminal statistics $[9,10$, 14]. The methods of simulation of crime prevalence [15], etc. are of particular interest.

However, when studying criminality, sometimes they do not take into account the reasons for the "fluctuations" of data of crime registration or its absence.

For example, the amendments into Art. 282 of the Criminal Code of the Russian Federation were made in 2018, they restricted the application of the stated norm, in particular, the ability to prosecute a person only after instituting administrative action against him or her for a similar act during one year. This reform caused a significant decrease in the registered extremism crimes (by 53.8\% following the results of 2019) [13]. However, if one will analyze the empiric data of criminality regardless of the described legal prerequisites, it is possible to make wrong conclusions about the results of fighting against extremism crimes.

Definitely, the empiric data of criminality statistics can be used with a certain degree of conditionality as they are subjected to the impact of the system of official statistics, in particular, the peculiarities of filling the documents of crime primary record by law enforcement officials.

For example, if a guilty person committed theft of the property by breaking the window of a dwelling but at the same time he or she did not enter the room, this act shall be qualified according to par. "a", part 3, Art. 158 of the Criminal Code of the Russian Federation (theft committed by home invasion). However, due to the regulatory directions contained in the order "United record of crimes", the General Prosecutor's office of Russia, Ministry of Internal Affairs of Russia, Ministry of Emergency Situations of Russia, Ministry of Justice of Russia, etc. [16] can consider this theft as committed in the public place as the source of property exemption was an apartment.

However, if due to the broken window, the guilty person does considerable damage to the victim, this act shall be additionally qualified according to Art. 167 of the Criminal Code of the Russian Federation as intentional destruction or damage of property. In this case, according to the requirements of the Order "United record of crimes", the mentioned crime is subjected to the record as committed in a public place.

As a result, two crimes, actually committed in one place ${ }^{1}$, have different social characteristics. This example reflects, to a great extent, the problems of criminality statistics in the country and in its turn impacts its criminological forecast.

\footnotetext{
${ }^{1}$ Here the scene of crime is understood not in its legal sense but as a physical location of a guilty person in the space.
} 
The normative requirements applied to the subjects of statistics cannot always correspond to the rules of crime qualification and thus can have a negative impact on the reliability of the statistical indicators. In particular, it refers to economic crimes that include also rigged matches.

Economic crimes as a rule are "divided" into separate episodes [17, pp. 54-55]. Thus, the created "artificial increase in the number of solved crimes by means of similar statistic manipulations influences the total number of registered crimes and consequently the dynamic indicators, distorts the structure of the registered criminality... As this part of the registered crimes does not exist in reality, however, it is reflected in the statistics and consciousness of researchers, let us call it "phantom" criminality... It should be understood as part of the registered crimes that has no real ground and it is reflected in the criminal statistics as a result of the unreasonable division of united crimes into independent episodes, falsification of statistical documents, and the use of other methods of intended distortion of criminal statistics" $[9,10]$.

When analyzing the dynamics of crime registration and the results of fighting against it, the peculiarities of report formation of activity results of law enforcement agencies should also be taken into account.

Shikhanov fairly remarks: "The work directed to the detection of corruption crimes focuses on the main reporting periods divided into quarters: three months, half a year, 9 months... In all certainty, it is possible to confirm that we can observe not the seasonable characteristics of corruption crimes but the work of formation of the required indicators to the required periods of the year and also oriented to the indicators of the same period of the previous year" $[18$, p. 66].

\section{Conclusion}

Factors referred to the regulation of criminal liability for the commitment of socially dangerous acts and official reporting of law-enforcement agencies about the results of their activity directed to the detection, solution, and investigation of crimes do not have a direct impact on the public processes that are related to the state of criminality, including sport. However, the empiric data of the crime statistics depend, to a great extent, upon the technical aspects, and are reflected in the indicators of the official statistics but not in the delinquent behavior of citizens.

Taking into account such close correlation between the main empiric data of the criminological research and changes in the legal framework of criminality and the order of recording of its symptoms, historical and legal analysis of the legal sources should be the first stage of the analysis of statistic fluctuations as many "abnormal" changes in the crime indicators can be caused by the amendments in the legislation but they are not related to the changes in society and the legal consciousness of the population.

The research was performed with the financial support of RFBR within the framework of the scientific project No. 20-011-00414 A "Criminal and criminological problems of fighting against the crime in the field of sport".

\section{References}

1. J.I. Kitsuse, A.V. Cicourel, Soc. Probl. 11(2), 131-139 (1963). https://doi.org/10.2307/799220

2. A.D. Vinogradova, Criminology Journal of Baikal National University of Economics and Law, 1, 172-176 (2014) 
3. J.A. Cooper, P.A. Collins, A. Walsh, Understanding and using statistics for criminology and criminal justice (Oxford University Press, New York, 2016)

4. L.V. Kondratyuk, Sistema kriminologicheskikh pokazatelei i metody ikh vychisleniya [System of criminological indicators and methods of their calculation] (All-Union Scientific Research Institute of the Ministry of Internal Affairs of the USSR, Moscow, 1976)

5. A.I. Dolgovoy (ed.), Kriminologiya: Uchebnik dlya vuzov [Criminology: Textbook for higher educational institutions] (Norma, Moscow, 2005)

6. D.A. Lee, Prestupnost v Rossii. Sistemnyi analiz [Criminality in Russia. System analysis] (Gelva, Moscow, 1997)

7. D. Tyagi, S. Sharma, Int. J. Eng. Tech. Mgmt. Res. 5(2), 67-74 (2018). https://doi.org/10.29121/ijetmr.v5.i2.2018.615

8. V.E. Novichkov, Prognozirovanie v sfere borby s prestupnostyu v sovrehmennoi Rossii [Forecast in the field of fighting against crime in the modern Russia], $\mathrm{PhD}$ thesis (Academy of Management of the Ministry of Internal Affairs of Russia, Moscow, 2006)

9. V.N. Shikhanov, Russian Law on the Internet, 4, 10 (2006)

10. V.S. Kamenkov, Physical Culture and Health, 48(1), 24-27 (2014)

11. M.P. Kleymenov, Herald of Omsk University. Series: Law 34(1), 201-203 (2013)

12. Ministry of Internal Affairs of Russia, Sostoyanie prestupnosti v Rossii za yanvar dekabr 2019 goda [State of criminality in Russia in January - December 2019]. Accessed on: July 15, 2020. [Online]. Available: https://мвд.pф/reports/

13. M.B. Short, M.R. D’Orsogna, V.B. Pasour, G.E. Tita, P.J. Brantingham, A.L. Bertozzi, L.B. Chayes, Math. Models Methods Appl. Sci. 18(supp01), 1249-1267 (2008). https://doi.org/10.1142/S0218202508003029

14. T. Sellin, J. Crim. Law Criminol. 41(4), 406-422 (1951)

15. R.P. Curiel, S.C. Delmar, S.R. Bishop, J. Quant. Criminol. 34(3), 775-803 (2018). https://doi.org/10.1007/s10940-017-9354-9

16. Rossiyskaya Gazeta, 13 (2006, January 25)

17. A.A. Aslakhanov, Problemy borby s prestupnostyu v sfere ekonomiki (Kriminologicheskii i ugolovno-pravovoi aspekty) [Problems of fighting against criminality in the sphere of economy (Criminological and criminal aspects)], $\mathrm{PhD}$ thesis (Moscow Law Institute, Moscow, 1997)

18. V.N. Shikhanov, O chem govorit statistika o borbe s prestupleniyami korruptsionnoi napravlennosti $v$ Rossii [What says the statistics about fighting against corruption crimes in Russia], in Korruptsiya: sostoyanie protivodeistviya i napravleniya optimizatsii borby: sbornik trudov konferentsii (Moskva, 27-28 yanvarya) [Corruption: state of fighting and directions of fighting optimization: collected works of the conference (Moscow, 27-28 January), 64-67 (Russian Criminological Association, Moscow, 2015) 